Article

\title{
Philosophical Enhancements of the Humanistic Phenomenology of Karol Wojtyla to the Thomistic Philosophy of the Human Person
}

Robert A. Montaña

\begin{abstract}
The capability of traditional Scholastic ethics to guide contemporary man in all his complexities has been called into question when Secular Humanism and, subsequently, Postmodernism have redirected attention from human acts to the agent person himself. While Secular Humanism has led to the advancement of science, and Postmodernism has instilled a resilient attitude in dealing with the issues of Modernism, the conceptual independence required in these philosophies and their corollary intellectual scientism has, at the same time, downgraded reliance on holistic and integrative knowledge, leading to a denial of the roles of faith, tradition, and authority in man's conceptual development. Karol Wojtyla's Personalism and Phenomenology emphasizes the primacy of the person without degrading the values inherent in action. Wojtyla's philosophy has bridged the ideals of traditional moral teachings with present-day pluralistic experiences when he situated freedom in the ego and when he grounded habit into the inner experience of man, rather than in character. With such freedom and self-determination, vertical transcendence becomes both experiential and personal. In this paper, I venture into how Wojtyla's thought has enhanced Thomistic philosophy by presenting an exposition of the various elements of The Acting Person vis-à-vis the discussions of the Angelic Doctor on parallel issues.
\end{abstract}

Keywords: Wojtyla, Aquinas, phenomenological personalism, human transcendence 


\section{Preliminary Notes}

$\mathrm{S}$ ince this paper revolves around the contributory elements provided by the philosophy of Karol Wojtyla to the notion of man as a subject in Thomism, I deem it best to first clarify the conceptual milieu affecting this endeavor. First, this paper opines that the philosophical understanding of man, as viewed from the Thomistic kaleidoscope, can be enhanced quantitatively by the empirical improvements of science and qualitatively by introducing novel conceptual notes of accidental relations into its overall paradigm. The latter differs from procedural attempts to substitute these paradigms themselves in the same way as some philosophers of the Enlightenment have sought to digress from a perceived static paradigm of medieval philosophy towards a more dynamic interpretation of reality by modern thinking. Second, Wojtyla's integration of the Aristotelian-Thomistic philosophy of the human person with the phenomenology of Max Scheler, conceptually improving on the latter-even to the point of transcending phenomenology itself ${ }^{1}-$ go beyond eclectic processes whereby the transcendence and dynamism of subject man are revealed and made more apparent. Third, the aforementioned contention, however, does not indicate that Scheler's phenomenology per se has foreshadowed this development; rather, it is assumed that it was Wojtyla's reinterpretation that has led to such enhancements both in the religious and philosophical spheres. ${ }^{2}$ Fourth, while it may be considered that Wojtyla has remained grounded on Thomistic categories while utilizing the language of phenomenology, any form of philosophical enhancement must be deemed propositional and argumentative for such to be ontogenetically actual and practical to human development. This position precludes any accusation that the contribution of Wojtyla could only be confined to semantic and syntactic linguistic ornamentations to traditional ethics. ${ }^{3}$

\footnotetext{
${ }^{1}$ Jameson Taylor argues that in Wojtyla's philosophy, there was a shift from a passive to an active epistemological emphasis on the human person. He writes: "What Wojtyla discovers is that the person is not simply an object of knowledge or a subject or a subject of experience but an 'agent of action' - an actor. By understanding the person as an actor, rather than only a subjectum or a subject, Wojtyla is attempting to overcome the limitations of metaphysics and phenomenology by reestablishing analysis of the person on a new plane." See Jameson Taylor, "Karol Wojtyla's Development of the Traditional Definition of Personhood," in The Review of Metaphysics, 63:2 (2009), 428.

2 Phenomenology per se, however, has its own contributions-expounded by Jude Dougherty - that has made it appealable even to Catholics. See Jude Dougherty, "Phenomenology as 'Ancilla Theologiae," in Angelicum, 82:2 (2005), 391-394.

${ }^{3}$ Joseph Lichten argues that Karol Wojtyla is a multi-faceted person in terms of talents, interests, and knowledge. If he is right, then any interpretation of his work is at best contingent. See Joseph Lichten, "A Pope of Great Hopes," in The Polish Review, 24, no. 2 Gaude Mater Polonia: Special Issue Dedicated to Karol Cardinal Wojtyla, John Paul II Pontifex Maximus (1979), 35.
} 


\section{PHILOSOPHICAL ENHANCEMENTS}

With these clarifications, I would proceed to argue the aspects by which Thomism may have been enhanced ${ }^{4}$ by the contributions of Karol Wojtyla.

\section{Contributory Avenues by Karol Wojtyla on Thomism}

Wojtyla begins his analysis of the acting person by an exposition of experience. This concept, established both by Thomas Aquinas and Karol Wojtyla as a cognitive process, normally involves the introduction of stimuli that initiates the epistemological process towards ideogenesis; yet, when the Angelic Doctor discussed ${ }^{5}$ as to whether angels understand singulars through experience as confined to phantasms and memories, he inadvertently exposed his opinion that they indirectly know singulars through the intelligible species imparted by God to them, ${ }^{6}$ thereby implying that experience as applied to them go beyond the sense-stimuli relation and is analogically applied only by way of similitude. ${ }^{7}$ Karol Wojtyla, however, stepped up and has applied this transcendence even to the human person by

4 Victor Salas has already argued as regards the ability of Thomistic philosophy to accommodate such an enrichment: “... Thomas, in articulating a creation metaphysics centered upon the act of existence (actus essendi) actually provides a successful means of establishing at least some of the features of selfhood, most especially personal incommunicability that so many phenomenological personalists hold dear. Indeed, it would seem that Thomas has the resources with which successfully to tether the axiological commitments of phenomenological personalism to a realist metaphysical foundation." See Victor Salas, "Thomas Aquinas's Metaphysics of the Person and Phenomenological Personalism: The Case of Incommunicability," in Gregorianum, 94:3 (2013), 577.

5 The discussion of St. Thomas Aquinas on the angels is quite interesting even for philosophers who are not religiously inclined because they are closer to God's spiritual nature, yet distinct as regards their essence and existence. In presenting his position that angels do not possess passive and active intellects, he expounds: "But each of these necessities is absent from the angels. They are neither sometimes understanding only in potentiality, with regard to such things as they naturally apprehend; nor, again, are their intelligible in potentiality, but they are actually such; for they first and principally understand immaterial things, as will appear later (Question 84, Article 7; Question 85, Article 1). Therefore there cannot be an active and a passive intellect in them, except equivocally." See Summa Theologiae (hereinafter ST) Ia. 54. 4c. See Thomas Aquinas, The Summa Theologica, translated by the Fathers of the English Dominican Province (Benziger Bros Edition, 1947).

${ }^{6}$ The Angelic Doctor explains thus: "Therefore as by His essence, by which He causes all things, God is the likeness of all things, and knows all things, not only as to their universal natures, but also as to their singularity; so through the species imparted to them do the angels know things, not only as to their universal nature, but likewise in their individual conditions, in so far as they are the manifold representations of that one simple essence." See ST Ia. 57. 2c.

${ }^{7}$ St. Thomas, in answering the argument that experimental knowledge emanating from experience is always discursive, clarifies that "[e]xperience is affirmed of angels and demons simply by way of similitude, forasmuch as they know sensible things which are present, yet without any discursion withal." Here he implies that experience can be philosophically distinct from discursiveness when applied to higher beings. See ST Ia. 58. 3. ad 3.

(C) 2021 Robert A. Montaña

https://www.kritike.org/journal/issue 28/montana june2021.pdf

ISSN 1908-7330

(cc) BY-NC-ND 
way of relation stating that any form of experience external to man is naturally reflexive, ${ }^{8}$ reverting to himself, thereby creating a cognitive relation with his personhood that is continuous, or at least, re-established whenever such is interrupted by sleep. We surmise here that Wojtyla, as a phenomenologist, has ventured into the thought that man's relation with phenomenon is not confined to specific instances of experience, but to this continuous totality that not only defines him but establishes who he is as a person. It seems that St. Thomas is aware of this relation because when he interpreted the manner in which Christ has advanced in wisdom, after he has established that He had perfect infused knowledge of all things, he argued that such an increase was made through experience by comparison of the intelligible species already in $\mathrm{Him}^{9}$ to what has been provided by the senses, thereby inverting the relation-where the person determines the phenomenon. Thus, we see here the interplay between the nature of the personhood and experience and on how, for both Wojtyla and St. Thomas, transcendence could be found primarily in the person. The difference, however, could be seen on how St. Thomas has confined discussions on this matter to Jesus Christ as the Logos and to the angels. On the other hand, Wojtyla went beyond the Angelic Doctor ${ }^{10}$ by applying such transcendence even to the imperfect human person as the seat of action, emphasizing this insofar as it reveals such personhood, ${ }^{11}$ utilizing an inductive process that is

${ }^{8}$ Wojtyla avers: "Man's experience of anything outside of himself is always associated with the experience of himself, and he never experiences anything external without having at the same time the experience of himself." Karol Wojtyla, The Acting Person (Dordrecht, Holland: D. Reidel Publishing Company, 1979), 3.

9 This advancement of knowledge was explained succinctly by the Angelic Doctor: "Therefore, if in the soul of Christ there was no habit of acquired knowledge, beyond the habit of infused knowledge, as appears to some [Blessed Albert the Great, Alexander of Hales, St. Bonaventure], and sometime appeared to me (Sent. iii, D, xiv), no knowledge in Christ increased in essence, but merely by experience, i.e. by comparing the infused intelligible species with phantasms. And in this way they maintain that Christ's knowledge grew in experience, e.g. by comparing the infused intelligible species with what He received through the senses for the first time. But because it seems unfitting that any natural intelligible action should be wanting to Christ, and because to extract intelligible species from phantasms is a natural action of man's active intellect, it seems becoming to place even this action in Christ." See ST IIIa. 12. 2c.

${ }^{10}$ Wojtyla also went beyond the Aristotelian tradition without contradicting it. Victor Salas avers: "Accordingly, Wojtyla places himself firmly within the Aristotelian metaphysical tradition, which understands a human being in terms of its hylomorphic substantiality specifically differentiated through rationality. However, Wojtyla goes considerably beyondalthough not contrary to-that same tradition when his account of the person unfolds in terms of an 'inner subjectivity', an 'inner life of self', proper only to persons." See Victor Salas, "The Analogical Structure of Self-Giving and Receiving according to John Paul II," in Gregorianum, 90:3 (2009), 476-477.

${ }^{11}$ James Liszka explains this interplay: "It is the mediating term of 'experience' which allows Cardinal Wojtyla to replace ethics with a phenomenological study, i.e., a study of the actions as they reveal themselves. The close correlation between person and action becomes 


\section{PHILOSOPHICAL ENHANCEMENTS}

not argumentative but one where the ego stabilizes its experience by recognizing sameness as it engages external reality. ${ }^{12}$

By dissociating the inductive method from the argumentative, Wojtyla further explores how induction leads to reduction, ${ }^{13}$ describing the latter as the process by which the abstract is grounded to the actual and real nature of man as he exists; as such, it is to "convert to suitable arguments and items of evidence or, in other words, to reason, explain, and interpret." 14 This explanation moves away from the standard understanding of reduction as the conceptual segregation of the non-essential elements of a thing as normally utilized by phenomenologists. ${ }^{15}$

One contributive element of such reduction is the piercing of the dynamic implications in the human act because while the emphasis on such as voluntary may include the notion of the actualization of the potentialities of the human subject, there remains the need to manifest this act not merely as a phenomenon but also as a part of a structure which is also ontic, and thus

manifest in experience." See James Liszka, "The Philosophical Thought of Cardinal Karol Wojtyla," in The Polish Review, 24:2 (1979), 31.

${ }^{12}$ It is in this arena where the notion of abstraction fuses with scientific induction. Wojtyla notes: "The transition from the multiplicity and complexity of 'factual' data to the grasping of their essential sameness, previously defined as the stabilization of the object of experience, is achieved by induction. At any rate this is how Aristotle seems to have understood the inductive function of the mind." See Wojtyla, The Acting Person, 14.

${ }^{13}$ The personalistic and phenomenological notion of Wojtyla's reduction has been aptly described by Juan Manuel Burgos: "Even more, and it is a central fact: they Wojtylian reduction has a vocation for radicality. It is not, by any means, a stroll by the surface of the phenomena. First of all because the Wojtylian 'phenomenon' does not consist of a set of elementary and fragmentary sensations but the human experience in all its depth and richness, that is to say, not only in its external and objective dimension (experience of man) but in self-experiential one. But, in addition, because the Wojtylian reduction specifically sets out to penetrate to the deepest possible level of research, that's to say, to get actually to the essence of man." This viewpoint emanates from a form of personalism that is specifically unique to Wojtyla when Burgos argued that our beloved pope's "philosophy does not exactly fit any of them [personalism], particularly the Thomistic personalism of Jacques Maritain." Burgos argued thus, however, without compromising Maritain's unique contribution - the "theoretical elaboration of communitarian personalism, understood as the determination of the set of relationships, priorities, and dependencies which configure the person' relation with society from a personalist point of view." Kindly refer to the following sources, respectively-Juan Manuel Burgos, "The Method of Karol Wojtyla: A Way Between Phenomenology, Personalism and Metaphysics," Phenomenology and Existentialism in the Twentieth Century: Book Two, Fruition-Cross PollinationDissemination, ed. by A-T Tymieniecka (Springer Netherlands, 2009), 114; Burgos, “Wojtyla's Personalism as Integral Personalism," in Quaestiones Disputatae, 9:2 (Spring 2019), 91; and Burgos, An Introduction to Personalism (The Catholic University of America Press, 2018), 53.

14 Wojtyla, The Acting Person, 17.

${ }^{15}$ While the analysis of the person is already a part of both theological and philosophical traditions, the contentions of personalism as a movement has been initially looked upon with suspicion, with The Acting Person contributing to its acceptance in the succeeding years. For a narrative of these transitions, see John Hellman, "John Paul II and the Personalist Movement," in CrossCurrents, 30, no. 4, (1980-1981), 409-419.

(c) 2021 Robert A. Montaña

https://www.kritike.org/journal/issue 28/montana june2021.pdf

ISSN 1908-7330

(cc) BY-NC-ND 
epistemologically approached as ontological. ${ }^{16}$ The implication of the person in action is already explicit in St. Thomas inasmuch as the Angelic Doctor recognizes the human person as the intrinsic principle of the voluntariness ${ }^{17}$ in human acts. ${ }^{18}$ Further, the Angelic Doctor establishes command as an act of reason, while presupposing the participation of the will, ${ }^{19}$ and such functions as the proximate cause of human acts. Hence, if there is such enhancement by Wojtyla of this traditional position, it would not be as regards the recognition of the person as the foundation of human acts; rather, it would be on the redirection of this reduction in the inverse direction. Whereby St. Thomas would venture outwards towards the objectification of human acts in relation to man's ultimate end, Wojtyla ventures backward towards the person, his voluntariness, and then towards his consciousness and experience. ${ }^{20}$ In this sense, we may construe this conceptual movement more as supplemental rather than as an explicit enhancement of the Thomistic emphasis.

One effect of such reduction is the extension of the notion of consciousness as implicit in the traditional exposition of the voluntary actin the sense that all voluntary acts are conscious ones. One notable advantage of Wojtyla is his exposure to conceptual developments in psychology and

${ }^{16}$ The consideration of act as emanating from man's dynamism is probably the greatest contribution of Wojtyla to phenomenological existentialism. He argues that: "... both action and conscious acting tell us of the dynamism proper to man as a person. It is owing to this intrinsic content that they comprise all that is meant by 'human act'; apparently philosophical thought has so far failed to develop a more fundamental concept for expressing dynamism apart from the concept of actus." See Wojtyla, The Acting Person, 27.

17 The Thomistic notion of voluntariness requires the active participation of reason and will; nonetheless, these are not exclusive since the sensitive appetites also play a role in its determination. For a discussion clarifying the distinctions in the analysis of voluntariness, kindly refer to Klaus Baumann, "The Concept of Human Acts Revisited: St. Thomas and the Unconscious in Freedom," in Gregorianum, 80:1 (1999), 156-158.

${ }^{18}$ The Angelic Doctor gave two requirements for a human act to be voluntary: "Hence it is that, according to the definitions of Aristotle, Gregory of Nyssa, and Damascene [See Objection $1]$, the voluntary is defined not only as having 'a principle within' the agent, but also as implying 'knowledge.' Therefore, since man especially knows the end of his work, and moves himself, in his acts especially is the voluntary to be found. See ST IaIIae. 6. 1c.

${ }^{19} \mathrm{St}$. Thomas thus explains the interplay of these two faculties: "I answer that, Command is an act of the reason presupposing, however, an act of the will. In proof of this, we must take note that, since the acts of the reason and of the will can be brought to bear on one another, in so far as the reason reasons about willing, and the will wills to reason, the result is that the act of the reason precedes the act of the will, and conversely." See ST IaIIae. 17. 1c.

${ }^{20}$ Wojtyla clarifies this movement: "In saying that the subject constitutes the fundamental expression of all man's experience, I wish to say at the same time that it is, first, an inviolable expression, for experience cannot be detached from it. Second, it is open to everything that man's experience, especially that of one's own self, may introduce into the understanding of the subjectivity of the person." See Karol Wojtyla, "The Person: Subject and Community," in The Review of Metaphysics, 33:2 (1979), 275. 


\section{PHILOSOPHICAL ENHANCEMENTS}

phenomenology in the study of consciousness-something outside the purview of the Angelic Doctor. The latter, however, made explicit his understanding of consciousness in his discussions on the comprehension of man in relation to God and happiness ${ }^{21}$ where he opined that the inclusion of the comprehended is in the person comprehending ${ }^{22}$ and is thus subject to the limitations of the latter, and that the comprehended can be retained by that person beyond the function of memory, making it a prerequisite for happiness. Further, in discussing whether the soul knows bodies through the intellect, the Angelic Doctor applied the principle that the intellectual and sensitive powers of man receive according to their own mode, affirming that science is of the intellect and thus it must be able to know matter through a process in accord with its nature. ${ }^{23}$ These two positions have repercussions on how consciousness was and should be treated in Thomistic philosophy.

Here we could observe that while the Angelic Doctor had some purview of consciousness as it related to human acts, it is almost always discussed in relation to an object insofar as the latter assimilates the intellectual species directly for knowledge or indirectly for perfection, such as happiness. Wojtyla, on the other hand, isolated or bracketed consciousness in terms of its mirroring, reflecting reality vis-à-vis the totality of conscious person, including everything that "happens" to him. In other words, Wojtyla agrees with the Angelic Doctor that comprehension is intentional in

21 The Angelic Doctor has, however, clarified the limitations of such comprehension when its object is God: "Comprehension is twofold. First, inclusion of the comprehended in the comprehensor; and thus whatever is comprehended by the finite, is itself finite. Wherefore God cannot be thus comprehended by a created intellect. Secondly, comprehension means nothing but the holding of something already present and possessed: thus one who runs after another is said to comprehend him when he lays hold on him. And in this sense comprehension is necessary for Happiness." See ST IaIIae. 4. 3. ad 1.

22 Whenever we would utilize Thomistic dichotomies to interpret Wojtyla, care should be given as regards how oppositions are dealt with by phenomenology. Jove Jim Aguas explains: "Wojtyla traced the root of this problem from the long history of Western thought. He noted that while the old antinomies that arose in the area of the theory of knowledge and formed a seemingly inviolable demarcation line between basic orientations in philosophy seemed to have been set aside and ignored in contemporary thought. The oppositions between subjectivism and objectivism, as well as that between idealism and realism turned to be discouraging discussions on human subjectivity." See Jove Jim Aguas, "The Notions of the Human Person and Human Dignity in Aquinas and Wojtyla," in Kritike: An Online Journal of Philosophy, 3:1 (June 2009), 49, $<$ http://www.kritike.org/journal/issue_5/aguas_june2009.pdf>.

${ }^{23}$ In other words, for St. Thomas, since the soul is principally spiritual, this epistemic process moves from the material to the immaterial in accord with the mode of the knower: "So also the intellect, according to its own mode, receives under conditions of immateriality and immobility, the species of material and mobile bodies: for the received is in the receiver according to the mode of the receiver. We must conclude, therefore, that through the intellect the soul knows bodies by a knowledge which is immaterial, universal, and necessary." See ST Ia. 84. 1c.

(C) 2021 Robert A. Montaña

https://www.kritike.org/journal/issue 28/montana june2021.pdf

ISSN 1908-7330

(cc) BY-NC-ND 
character, ${ }^{24}$ yet when its object is contained in consciousness, the latter takes on a unique perspective which was never directly discussed by the Angelic Doctor. For Wojtyla, it even appears that classical phenomenological positions contained these assumptions of the Angelic Doctor-that is, essentially associating consciousness with intentional cognition. He teaches us, on the other hand, that beyond such consciousness is the existence of an intrinsic cognitive act that links it to the dynamism and efficacy of the human person. The fruition of this cognitive act is self-knowledge, where the subject becomes the object, forming a coherence with consciousness that serves as the foundation of equilibrium in man's inner life. When a man chooses evil, for instance, he not only commits an evil act, he also knows that what he is doing is evil, and he is aware of this knowledge. In this sense, he not only performs an evil act, but he also makes a choice that permeates his entire humanity the subjectivation of the objective. ${ }^{25}$ This is a novel contribution neither found in classical Thomistic ${ }^{26}$ nor in phenomenological discussions.

Wojtyla, however, clarifies that this duality of consciousness attains the limitation of subjectivation through experience by objectifying one's awareness of his own being; and from this perspective, a clearer understanding of how spirituality is manifested in consciousness is achieved. ${ }^{27}$ Etymologically, spirare or "to breathe" associates the traditional

${ }^{24}$ The correlation between cognition and intentionality is clear in the philosophy of our beloved pope: "It lies in the essence of cognitive acts performed by man to investigate a thing, to objectivize it intentionally, and in this way to comprehend it. In this sense cognitive acts have an intentional character, since they are directed toward the cognitive object; for they find in it the reason for their existence as acts of comprehension and knowledge." See Wojtyla, The Acting Person, 31-32.

${ }^{25}$ This subjectivation occurs when cognition is treated beyond the metaphysical towards the consideration of cognition principally as human. Karol Wojtyla explains: "Although I acknowledge the specificity and distinctness of metaphysical cognition, I deny that it can be separated from the rest of human cognition, for all cognition is metaphysical through its roots inasmuch as it reaches being. This, of course, does not diminish the meaning of the particular aspects of being which are necessary to understand its full richness. The discovery of the human subject, or man's subjectivity in the metaphysical sense, opens at the same time a fundamental approach to the relation between existence and action." See Karol Wojtyla, "The Person, Subject and Community," 275.

${ }^{26}$ Etienne Gilson, however, in interpreting the teachings of St. Thomas, explains that: "The proper object of the intention is the end willed in itself and for itself. It constitutes, therefore, a simple act and, so to speak, an indecomposable movement of our will. But voluntary activity becomes extremely complex when we pass from the intention of the end to the choice of the means... [t]his opting is the actual electing or choosing, and is itself preceded by deliberation and judgment." Here we see that contemporary interpretations of the Angelic Doctor do not substantially digress from Wojtyla's teachings, showing that the latter's philosophy may be latent in the Summa Theologiae. See Etienne Gilson, The Christian Philosophy of St. Thomas Aquinas (Notre Dame Press, 1956), 253.

${ }^{27}$ I surmise that, with this position, the influence of Fr. Reginald Garrigou-Lagrange, O.P. to the thinking of Karol Wojtyla is apparent. In line with this, John Grondelski opines that Neo- 


\section{PHILOSOPHICAL ENHANCEMENTS}

notion of spirituality to some form of universal principle of vitality. In this sense, it is synonymous with the functional expression of the soul; and in the scholastic age, it was thus conceptualized as the substantial form of man. When St. Thomas tackled the issue as to whether the soul of man is of God's substance, he replies in the negative and clarifies that spirare as breath should not be taken materially, associating the term, on the other hand, with the making of a spirit, distinguishing the soul from $\operatorname{God}^{28}$ and considering it as subsistent ${ }^{29}$ yet moved accidentally. ${ }^{30}$ From such descriptions, the concept of transcendence is naturally attached to the spirituality of the soul inasmuch as it is neither a body ${ }^{31}$ nor an accident yet remains finite. Transcendence, however, is specific to those creatures whose powers emanate from the soul not only as a principle but also as a subject. ${ }^{32}$ Thus, from the perspective of

Scholastic Thomistic Realism is one of the pre-papal influences of Wojtyla, specifically because of Fr. Garrigou-Lagrange. This is not surprising because of the latter's attempt to merge Thomistic Philosophy with the mystical experience of the saints-bridging the gap between subjectivity and objectivity. See John Grondelski, "Prepapal Influences on John Paul II's Thought," in New Blackfriars, 78:911 (1997), 30-31.

${ }^{28}$ St. Thomas avers: "The term 'breathe' is not to be taken in the material sense; but as regards the act of God, to breathe [spirare], is the same as to 'make a spirit.' Moreover, in the material sense, man by breathing does not send forth anything of his own substance, but an extraneous thing." See ST Ia. 90. 1. ad 1.

${ }^{29}$ Such subsistence, as explained by the Angelic Doctor, emanates from the soul's capacity to operate independently of the body: "Therefore the intellectual principle which we call the mind or the intellect has an operation 'per se' apart from the body. Now only that which subsists can have an operation 'per se.' For nothing can operate but what is actual: for which reason we do not say that heat imparts heat, but that what is hot gives heat. We must conclude, therefore, that the human soul, which is called the intellect or the mind, is something incorporeal and subsistent." See ST Ia. 75. 2c.

${ }^{30}$ It seems that, for St. Thomas, the lack of distinction between essential and accidental movements in terms of movers may lead to the idea that souls, like material beings, are also moved essentially rather than accidentally: "There is, however, another kind of mover, which, though not moved essentially, is moved accidentally; and for this reason it does not cause an invariable movement; such a mover, is the soul. There is, again, another mover, which is moved essentially-namely, the body. And because the philosophers of old believed that nothing existed but bodies, they maintained that every mover is moved; and that the soul is moved directly, and is a body." ST Ia. 75. 1. ad 1.

${ }^{31}$ While Wojtyla considers traditional philosophy as the foundation of personalism, phenomenology has had certain influences on his overall approach to this perspective. John Coughlin explains: "While careful not to accept a primarily subjective view of the human person. Wojtyla shared the phenomenologists' rejection of the mind-body dualism and of an overly cognitive approach to human knowing. He relied on phenomenological method to analyze the valid function of the body and emotions in the perception of value. In approaching the human person as constituted through action, Wojtyla sought to employ phenomenological method as an affirmation of Thomist objective morality." See John Coughlin, "Canon Law and the Human Person," in Journal of Law and Religion, 19:1 (2003-2004), 12-13.

32 St. Thomas explains: "As we have said already (Articles 5,6,7), all the powers of the soul belong to the soul alone as their principle. But some powers belong to the soul alone as their subject; as the intelligence and the will. These powers must remain in the soul, after the

(C) 2021 Robert A. Montaña

https://www.kritike.org/journal/issue 28/montana june2021.pdf

ISSN 1908-7330

(cc) BY-NC-ND 
Thomistic philosophy, there is also transcendence in man inasmuch as he has a soul; however, Wojtyla introduces another novel aspect-a person's transcendence in action. He explains that the traditional notion of transcendence is a negation of material qualities. He avers, however, that transcendence must go beyond abstraction towards the kind of intuitional shape that concretely represents human life where life and fulfillment could establish its ground. ${ }^{33}$ In this sense, for instance, truthfulness in man ought to move towards his decision to surrender to this truth; and thus, holistically, there should be a parallel movement from the mere acknowledgment of the manifestations of spirituality to the very root of such spirituality-man who is a spirit both in the phenomenological and ontological sense.

The function of consciousness to allow man to experience himself as a subject leads to a two-fold consideration that the aspect of being a "man" or a "person" is ultimately reducible to the aspect of consciousness, while the aspect of "acting" as a person falls within the domain of experience. He further explains that utilizing this distinction in the analysis of man and his action goes beyond mere methodology; 34 on the other hand, it clarifies the issue on how problems in the subjective level may emanate from disorders in the objective level. ${ }^{35}$ We must remember that, as a personalist ${ }^{36}$ and as a

destruction of the body. But other powers are subjected in the composite; as all the powers of the sensitive and nutritive parts." The distinction by the Angelic Doctor as regards powers that are inherently situated in the soul as subject rather than as mere principle may have been the starting point of Wojtyla's notion of transcendence with the enhancement that such extends also to acts of such transcendent person. See ST Ia. 77. 8c.

33 Our beloved pope explains that transcendence is the source of the cognition of spirituality in man, following certain steps, to wit: "The sequence of our comprehensions in this respect is as follows: to start with, we recognize that man is the person; next, that his spiritual nature reveals itself as the transcendence of the person in his acting; and finally, that only then can we comprehend in what his spiritual being consists." See Wojtyla, The Acting Person, 181-182.

34 Pope John Paul II did not merely offer a conceptual methodology as regards the consistency between person and act. His visit to the Philippines in 1981 concurrently showed his disgust over the lack of proportion between government action on the legitimate defense of the state vis-a-vis the violations of human rights, warning Marcos himself on such disregard. For a short narration on this, read George Huntston Williams, "John Paul II's Concepts of Church, State, and Society," in Journal of Church and State, 24:3 (1982), 493.

35 The beloved pope specifically applies this to the interplay between the acting person's subjectivity and the object of his experience, and on how one influences the other. He notes: "Without completely revealing this subjectivity it is also impossible to reach and bring to light the whole, objectively multifarious composition of those factual data. It is important to stress, however, that the bias of subjectivism may also develop in connection with a narrow and onesided bias of objectivism." See Wojtyla, The Acting Person, 57-58.

${ }^{36}$ Krzysztof Dybciak and Alice-Catherine Carls both reveal that Wojtyla exhibited tendencies of active personalism in his literary writings prior to the publication of his philosophical works. See Krzysztof Dybciak and Alice-Catherine Carls, "The Poetic Phenomenology of a Religious Man: About the Literary Creativity of Karol Wojtyla," in World Literature Today, 54:2 (1980), 229.

(C) 2021 Robert A. Montaña

https://www.kritike.org/journal/issue 28/montana june2021.pdf

ISSN 1908-7330 


\section{PHILOSOPHICAL ENHANCEMENTS}

phenomenologist, Wojtyla associates the formation of man's Weltanschauung within the fusion of horizons between objective reality and man's experience, ${ }^{37}$ with the latter reducible as an aspect of consciousness.

Although this position might be phenomenological, and hence a contemporary issue, St. Thomas has indirectly tackled this topic when he discussed whether the will is evil when it is in variance with an erring reason. ${ }^{38}$ In dealing with this, the Angelic Doctor was reacting to an argument - which probably emanated from the Franciscans - that the will should follow an erring reason only in matters that are indifferent; on the other hand, for matters which are objectively good or evil, then the will must no longer follow an erring reason. While this may be ideal, it is not realistic because an erring reason is basically unable to determine objectivity; and in order to resolve this, he introduced the notion of "accidental apprehension," taking on the scenario that an erring reason errs precisely because it digresses from reality. Unwittingly perhaps, the Angelic Doctor stepped on a phenomenological issue because in this problem, the Angelic Doctor takes on the situation of the will as dependent on reason as it moves towards good or evil; and with its guide in error, right or wrong - on the part of the willwould now depend on how it follows or digresses this erring reason. Thus, in his example, if belief in Christ (which is good in itself) is presented by reason as evil, then the will would end up paradoxically committing evil if it pursues this belief. Some theologians thus pursued the notion that one should follow an erring reason; however, I have argued against this elsewhere, instead offering an alternative imperative. ${ }^{39}$ It would not be surprising then

37 This Weltanschauung has real life consequences. Paul Muscari laments: “Certainly in a world where the subject is often looked upon as an object of clinical study, or as the term of a proposition about which something is affirmed or denied; where human beings, like atoms of sodium, are frequently divested of anything that distinguishes them from others; and where 'personhood' has become a normative classification that has been extended to inanimate corporations but not to human fetuses, there would seem to be an urgent call for a more personcentered perspective." See Paul Muscari, "On Human Nature: A Look at the Subject from Karol Wojtyla's Work 'The Acting Person," in The Journal of Mind and Behavior, 9:1 (1988), 14.

${ }^{38}$ The Angelic Doctor is aware of the dependence of the will on what reason presents as good, making him, in this sense, phenomenologically cognizant of the interplay between reality and experience. He cites this example: "For instance, to refrain from fornication is good: yet the will does not tend to this good except in so far as it is proposed by the reason. If, therefore, the erring reason propose it as an evil, the will tends to it as to something evil. Consequently the will is evil, because it wills evil, not indeed that which is evil in itself, but that which is evil accidentally, through being apprehended as such by the reason." See ST IaIIae. 19. 5c.

${ }^{39}$ Instead, I offered the following guideline: "One's conscience should always follow reason in pursuit of good after fully ascertaining its consistency with morality and law." While error in reason is sometimes unavoidable, the guideline mandates that an effort be made to dispel such and if circumstances had made it impossible, the error would then be the result of invincible ignorance. See Robert Montaña, Thomistic Ethics: A Beacon in the Contemporary Moral Landscape, (Manila: University of Santo Tomas Publishing House, 2015), 56-59.

(C) 2021 Robert A. Montaña

https://www.kritike.org/journal/issue 28/montana june2021.pdf

ISSN 1908-7330

(cc) BY-NC-ND 
for Wojtyla to assert that both the reference and inner dependence on the truth is founded on the human will. ${ }^{40}$ This interplay of Wojtyla's position on the relationship between consciousness and experience is implied in the discussions of the Angelic Doctor, yet we may construe that the exploration of such relations had been clarified in these contemporary times.

Wojtyla further elaborates on the traditional dichotomy between human acts and acts of man by introducing the concept of efficacy-man's experience of being the person behind his acts. Through such efficacy, man can distinguish things that merely happen to him from that which principally and practically emanates from him. Efficacy, in this sense, is not directly discussed by St. Thomas; yet Wojtyla considers it essential because it leads to the realization as regards the causal relation between the person and his acting. ${ }^{41}$ The focal point here is not just the relation, however, but the realization that once action is ultimately traced to the person, then the notion of stability or permanence is simultaneously established. In a loose sense, St. Thomas implies this idea in his treatise on habits as a disposition-either properly or improperly. ${ }^{42}$ Arguing as regards to whether habit implies order to an act, the Angelic Doctor explains that habit refers to the disposition of nature, ${ }^{43}$ and that the latter is further ordained to operation, or the product of such operation. Since habit is prior to power as a principle of act in this sense, then habit and act are principally related. ${ }^{44}$ Afterward, in dealing with

${ }^{40}$ For our beloved pope, this dependence is especially apparent in the experience of guilt: "But it is the reality of guilt-of sin or moral evil-known from the moral experience that brings to light explicitly the fact that the reference to truth and the inner dependence on truth is rooted in the human will." See Wojtyla, The Acting Person, 139.

${ }^{41}$ Such cause-effect relationship, according to our beloved pope, is essential: "Hence, it is first necessary to demonstrate why and when the act of man is not human acting; for only then will it be possible to understand why human acting alone is the acting proper to man, that it alone corresponds to what actually is contained in the structure of 'man-acts." Ibid., 66-67.

42 The Angelic Doctor here considers habit in the sense in which it functions as a determining mode: "For quality, properly speaking, implies a certain mode of substance. Now mode, as Augustine says (Gen. ad lit. iv, 3), 'is that which a measure determines': wherefore it implies a certain determination according to a certain measure" and "For when the mode is suitable to the thing's nature, it has the aspect of good: and when it is unsuitable, it has the aspect of evil. And since nature is the first object of consideration in anything, for this reason habit is reckoned as the first species of quality." See ST IaIlae. 49. 2c.

${ }^{43}$ It should be clear at this point, however, that natural law is not the starting point in Wojtyla's analysis of the acting person. John Grondelski clarifies: “Wojtyla's ethical point of departure is not, however, natural law per se. Rather, Wojtyla begins with the human person. The person is a subject. He can be related to by way of love or by way of use. Given the kind of being that the person is, the only ethical posture by which one person can relate to another is one of love. To use the person is to be unjust, to deny his personhood, to treat him as a thing, to reify him." See John Grondelski, "Nature and Natural Law in the Pre-Pontifical Thought of John Paul II," in Angelicum, 72: 4 (1995), 522.

${ }^{44}$ The Angelic Doctor expounds on this: "If therefore the nature of a thing, in which the habit is, consists in this very relation to an act, it follows that the habit principally implies relation 


\section{PHILOSOPHICAL ENHANCEMENTS}

whether habits are subject to increase or decrease, the Angelic Doctor teaches that the perfection of a form is considered in respect to itself and also in respect of its participation in a subject, concluding that in the case of the former, receiving nature in respect of itself, then it becomes definiteespecially as applied to substance-while in the case of the latter, being susceptible to more or less becomes possible. Thus, while healthy per se could be considered as indivisible, having more or less of it in individuals could be effectuated. ${ }^{45}$ Thus habits, which are potential to either nature or power, could be found severally in the same subject, providing an overall disposition of the latter. ${ }^{46}$ Efficacy, as taught by Wojtyla, basically follows the same causal relation of this Thomistic will-based person-habit link, with the integration of consciousness founded on the intellect specifically perfecting the will, leading to the realization that the commanded acts of the will recreate his disposition - through the clarity of consciousness-without compromising the definiteness and unity of his nature. The role of consciousness leading to efficacy or the experience of being the actor to the Thomistic teachings on habit is another unique enhancement by Wojtyla. ${ }^{47}$

to an act. Now it is clear that the nature and the notion of power is that it should be a principle of act. Wherefore every habit is subjected in a power, implies principally relation to an act." See ST IaIIae. 49. 3c.

${ }^{45}$ While a distinction could be made as regards the excellence of a form and its degree of participation by a subject, St. Thomas nonetheless clarifies that this does not assign a separate ontic status to that form itself: "Now the perfection of a form may be considered in two ways: first, in respect of the form itself: secondly, in respect of the participation of the form by its subject. In so far as we consider the perfections of a form in respect of the form itself, thus the form is said to be "little" or "great": for instance great or little health or science. But in so far as we consider the perfection of a form in respect of the participation thereof by the subject, it is said to be "more" or "less": for instance more or less white or healthy. Now this distinction is not to be understood as implying that the form has a being outside its matter or subject, but that it is one thing to consider the form according to its specific nature, and another to consider it in respect of its participation by a subject." See ST IaIIae. 52. 1c.

${ }^{46}$ In the light of the argument of St. Thomas that an active power cannot be the subject of habits, the will being a passive power becomes the subject of the disposition of several habits: "Wherefore, just as several objects can move one passive power, so can one passive power be the subject of several acts or perfections specifically diverse. Now habits are qualities or forms adhering to a power, and inclining that power to acts of a determinate species. Consequently several habits, even as several specifically different acts, can belong to one power." See ST IaIIae. 51. 2c and ST IaIIae. 54. 1c.

47 This enhancement may also benefit not only Thomism, but also phenomenology itself. Hans Kochler asserts: “All the same, Wojtyla's conception does not allow us (as we have been trying to demonstrate) to visualize consciousness as something absolute in the ontological sense. This means a continuation of the realistic tradition of phenomenology and, at the same time, renouncing the reification of an empirical and finite consciousness by hypostatizing it to a socalled "pure" consciousness which is understood then as fundamental dimension of reality (of being "real") (as it is expressed in Husserl's transcendental phenomenology)." See Hans Kochler, "The Phenomenology of Karol Wojtyla: On the Problem of the Phenomenological Foundation of Anthropology," in Philosophy and Phenomenological Research, 42:3 (1982), 332.

(c) 2021 Robert A. Montaña

https://www.kritike.org/journal/issue 28/montana june2021.pdf

ISSN 1908-7330

(cc) BY-NC-ND 
The emphasis on the essence of the person leads us to the parallel discussion made both by Wojtyla and St. Thomas on the definition of a person by Boethius: "a person is an individual substance of a rational nature." It should be noted, however, that for the Angelic Doctor, this notion was initially considered in his treatise on God, and subsequently on the human person. Wojtyla, on the other hand, makes it clear that, for him, the elements "rational" and "individual" are not enough to describe the totality of the human person. ${ }^{48}$ In the Angelic Doctor's discussion on this Boethian definition, most of the objections stemmed from the improper insertion of the word "individual," noting that singulars are not supposed to be part of any definition. St. Thomas ${ }^{49}$ dealt with this by clarifying that individuals, in certain special ways, belong to substances, and are thus considered as "first substances." ${ }^{50}$ When these "first substances" act of themselves in a rational way, then these are termed as "persons." Here we could see that the Angelic Doctor indirectly associated freedom with personhood. While St. Thomas considers this definition as sufficient, Wojtyla opines that the issue is more than a discourse on the concreteness of the substance-it is rather the difference of a person as "someone" from the other which is called "something," with the former having a different ontological structure than the latter. ${ }^{51}$

${ }^{48}$ Our beloved pope explains thus: “The person is a concrete man, the individua substantia of the classical Boethian definition. The concrete is in a way tantamount to the unique, or at any rate, to the individualized. The concept of the 'person' is broader and more comprehensive than the concept of the 'individual,' just as the person is more than individualized nature." See Wojtyla, The Acting Person, 73-74.

49 The Angelic Doctor clarifies this: "Although the universal and particular exist in every genus, nevertheless, in a certain special way, the individual belongs to the genus of substance. For substance is individualized by itself; whereas the accidents are individualized by the subject, which is the substance; since this particular whiteness is called "this," because it exists in this particular subject. And so it is reasonable that the individuals of the genus substance should have a special name of their own; for they are called "hypostases," or first substances." See ST Ia. 29. 1 c.

${ }^{50}$ As regards this definition, Lu Jiang comments: "But in Thomas' notion of <<person>>, what stands out is not substantiality but singularity, as is clear from the context in the Summa. With $<<$ person $>>$ signifying a subsistent individual or a rational nature, the individuality denoted by $<<$ person $>>$ is found in a more special and perfect way in rational substances, which have dominion over their acts i.e. the ability to act according to reason and freely, being the efficient cause of their own acts." See Lu Jiang, "Person and freedom in Thomas Aquinas' philosophy," in Divus Thomas, 121:3 (2018), 360.

51 The notion that Wojtyla treated Thomistic Ontology as the foundation of his philosophy is generally agreed upon. Jerry Galkowski explains: “... K. Wojtyla's analyses of man have been made upon the basis of the traditional philosophy of being, and in this case, Thomism. Obviously this is not only an exegesis of Thomism, but the creative development of it through an organic synthesis with contemporary philosophy, particularly with phenomenology, although the accent upon the personal character of the human esse constitutes a step in the direction of existential thought." Here we see that there is also a consensus that Wojtyla's 


\section{PHILOSOPHICAL ENHANCEMENTS}

Surprisingly, however, Wojtyla introduced the question as to whether person and nature are conceptually integrated or in opposition against each other. Educing the various meanings of nature, Wojtyla noted the following: first, nature is etymologically founded on the notion of being born; second, the substantive meaning of nature leads to the consideration of both animate and inanimate elements (the latter Wojtyla believes should not be included) of the material world; third, such may also be construed as a property of an object, or even of the essence itself. ${ }^{52}$ These meanings do not digress substantially to the Scholastic textbook teaching that nature is essence in its active sense. St. Thomas, on the other hand, had the same understanding of nature: first, he also expounded on the etymology of the word "nature" 53 and when he discussed whether virtue is natural to man's individual or specific nature, he linguistically utilized "nature" as something initially inchoate and inherent; ${ }^{54}$ second, the Angelic Doctor also referred to God as the universal author of nature, signifying the latter as the totality of creation; ${ }^{55}$ and third, in the discussions on the simplicity of God, he equated essence with nature. 56

contribution is the creative restructuring of traditional concepts. See Jerzy Galkowski, "The Place of Thomism in the Anthropology of K. Wojtyla," in Angelicum, 65:2 (1988), 193.

${ }^{52}$ Although in Scholastic circles, the notion of nature denotes essence in its active sense, our beloved pope nonetheless emphasizes its dependence on the real existence of its subject: "Nature does not denote a real and actual subject of existing and acting; it is not to be identified with the ontological foundation of a being. It can only apply to an abstract subject. For instance, in speaking of human nature we refer to something which has the status of real existence as the ontological structure of man only in an actual human being, but which has no real existence apart from him." See Wojtyla, The Acting Person, 77.

53 St. Thomas clarifies the meaning of "nature" as utilized in his discussion on how the union of the Incarnate Word took place: "Now this principle [of motion] is either form or matter. Hence sometimes form is called nature, and sometimes matter. And because the end of natural generation, in that which is generated, is the essence of the species, which the definition signifies, this essence of the species is called the "nature." And thus, Boethius defines nature (De Duab. Nat.): "Nature is what informs a thing with its specific difference,"---i.e. which perfects the specific definition. But we are now speaking of nature as it signifies the essence, or the "what-itis," or the quiddity of the species." We could notice that for the Angelic Doctor, nature signifies the essence of the perfected species, while for Wojtyla, nature signifies man's ontological structure in an actual human being. Here we could observe a shift from an epistemological to a metaphysical emphasis of the understanding of "nature." See ST IIIa. 2. 1c.

54 The Angelic Doctor explains thus: "In both these ways virtue is natural to man inchoatively. This is so in respect of the specific nature, in so far as in man's reason are to be found instilled by nature certain naturally known principles of both knowledge and action, which are the nurseries of intellectual and moral virtues, and in so far as there is in the will a natural appetite for good in accordance with reason." See ST IaIIae. 63. 1c.

${ }^{55}$ St. Thomas argued that: "... the general intention of nature depends on God, Who is the universal Author of nature." See ST Ia. 92. ad 1.

${ }^{56}$ In the following, we could observe that the Angelic Doctor repeatedly equated essence with nature: "God is the same as His essence or nature. To understand this, it must be noted that in things composed of matter and form, the nature or essence must differ from the 'suppositum,'

(C) 2021 Robert A. Montaña

https://www.kritike.org/journal/issue 28/montana june2021.pdf

ISSN 1908-7330

(cc) BY-NC-ND 
Here we see that as regards the understanding of nature, Wojtyla did not digress from the teachings of St. Thomas. Wojtyla, however, introduced a somewhat surprising thesis - that person and nature could be conceived antagonistically. ${ }^{57}$ I mentioned "surprising" because nowhere in traditional Scholasticism could we see an exposition of this position. For Wojtyla, this distinction would paradoxically create two worlds - the world of the person and the world of nature, with the latter creating an emphasis on the dynamism of man but not to the point of establishing a holistic recognition of the subject of this dynamism. In other words, there would be a tendency to disregard such subject in favor of an aspect of dynamism. The Angelic Doctor is aware of such distinction and this was shown when he discussed whether God is the same as His essence or nature, explaining that in things that are composed of matter and form-such as man-essence or nature is distinguished from "suppositum" leading to the conclusion that a man would not be exactly equal to humanity, although the latter would function as a formal aspect. ${ }^{58}$ From this, we surmise that, although both Wojtyla and St. Thomas are aware of the distinction between nature and its subject, Wojtyla goes beyond the simple distinction of Thomism and warns of wanton disregard of the acting person in favor of function-something which is apparent in contemporary times. ${ }^{59}$

because the essence or nature connotes only what is included in the definition of the species; as, humanity connotes all that is included in the definition of man, for it is by this that man is man, and it is this that humanity signifies, that, namely, whereby man is man." See ST Ia. 3. 3c.

${ }^{57}$ Care should be given in interpreting this position because what Wojtyla is warning us about is the act of giving more emphasis to nature than to man. This should not be construed as a statement against science; in fact, he believes otherwise. Albert Bagood clarifies: "The late Pope John Paul II's interest in the Galileo-case and in the evolution-genome issue is not a product of a strict scientific formation. It is a consequence of a firm belief in the complementarity of science and faith." See Albert Bagood, "John Paul II's Discrete Eye for Science," in Angelicum, 82:2 (2005), 356.

${ }^{58}$ The Angelic Doctor argued thus: "For this particular flesh, these bones, this blackness or whiteness, etc., are not included in the definition of a man. Therefore this flesh, these bones, and the accidental qualities distinguishing this particular matter, are not included in humanity; and yet they are included in the thing which is man. Hence the thing which is a man has something more in it than has humanity. Consequently humanity and a man are not wholly identical; but humanity is taken to mean the formal part of a man, because the principles whereby a thing is defined are regarded as the formal constituent in regard to the individualizing matter." See ST Ia. 3. 3c.

${ }^{59}$ Bernard Gendreau describes this endeavor: “The common enterprise was to rethink the notion of person in all its potential and the notion of society in all its facets in the context of the crisis brought about by the legacy of modern philosophy present in Europe with its outcome of a dehumanizing individualism and a depersonalizing totalitarianism in the effort to overcome the encroachment of the person by society and of society by the individual and to promote the person in its own dignity." See Bernard Gendreau, "The Role of Jacques Maritain and Emmanuel Mounier in the Creation of French Personalism," in The Personalist Forum, 8:1 (1992), 98.

(c) 2021 Robert A. Montaña

https://www.kritike.org/journal/issue 28/montana june2021.pdf

ISSN 1908-7330 


\section{PHILOSOPHICAL ENHANCEMENTS}

Such antagonism, according to Wojtyla, could be resolved through a process by which the dynamism of man is synthesized, leading to the recognition that action has man as its existential ontological support. ${ }^{60}$ This was also indirectly affirmed by St. Thomas when he averred that existence makes nature actual and thus correlatively related to essence as act to potency. ${ }^{61}$ Wojtyla contributes here by way of emphasis as this relation is applied to man in such a way that, because of humanity, a person is set towards a nature that is proper to it, with acts that further define this nature, and that any digression goes against the forces that makes him a human person.

The dynamism of man makes him a being-in-becoming, and from this consideration, comes the manifestation of freedom. Wojtyla avers that this dynamism establishes the instance of becoming in man, and based on earlier considerations, this progression does not merely make something out of him, but also somebody out of him. ${ }^{62}$ In this sense, according to Wojtyla, a man becomes good or bad in the light of his freedom. He further explains that the experience of the human person who would "want" something is a fusion of the notions "I need not" and "I may," exposing the possibilities available in the horizon of his dynamism. ${ }^{3}$ In this sense, man being both dynamic and transcendent becomes such by virtue of his freedom. ${ }^{64}$ St. Thomas indirectly

${ }^{60}$ Thus, in this sense, any interpretation of action must hitherto be related to the actual person as human. Our beloved pope explains: "With this element the whole interpretation of the person-action relation confirms its human import. Acting and happening are both human insofar as they derive within the person from nature, from the humanness of man. It is the person itself that is human and so are its actions." See Wojtyla, The Acting Person, 84-85.

61 The Angelic Doctor expounds on this relation: "Secondly, existence is that which makes every form or nature actual; for goodness and humanity are spoken of as actual, only because they are spoken of as existing. Therefore existence must be compared to essence, if the latter is a distinct reality, as actuality to potentiality." See ST Ia. 3. 4c.

${ }^{62}$ Our beloved pope expounds on this: "Having come substantially into existence, man changes one way or another with all his actions and with all that happens in him: both these forms of the dynamism proper to him make something of him and at the same time they, so to speak, make somebody of him." See Wojtyla, The Acting Person, 96-97.

${ }^{63}$ Even in his real-life decision, Karol Wojtyla believed in this dynamism. Gracjan Kraszewski writes: "Pope John Paul II, as Wojtyla was now known, was not content with sitting in Rome and merely giving moral support to his home country. As soon as time allowed, he planned to make a pilgrimage to his homeland. That historic visit, from June 2 through June 10, 1979 , is the focus of this article. The Pope's first trip to Poland awoke a religious zeal and national pride that had lain largely dormant for years under the weight of the Soviet rule. This 'renaissance' produced significant consequences both within Polish borders and beyond, serving as the glue of the 1980's Solidarity movement (Solidarnosc) and, therefore, helping to facilitate the collapse of Polish communism and indeed the entire Soviet Union." See Gracjan Kraszewski, "Catalyst for Revolution: Pope John Paul II's 1979 Pilgrimage to Poland and Its Effects on Solidarity and the Fall of Communism," in The Polish Review, 57:4 (2012), 28.

${ }^{64}$ Expressed inversely, the dynamism of man as a subject is clarified by a proper understanding of freedom. Our beloved pope explains thus: "The discovery of freedom at the

(c) 2021 Robert A. Montaña

https://www.kritike.org/journal/issue 28/montana june2021.pdf

ISSN 1908-7330

(cc) BY-NC-ND 
made a reference to this interaction when he discussed what constitutes a state among men and whether this denotes a condition of freedom or servitude. He averred that a state signifies something stable in his nature, in contrast to those matters which are both contingent and external to such a nature, citing as examples wealth and rank. He followed this up with the clarification that freedom or servitude-being subject to another-and the obligation that emanates from this is also something stable, and thus a consideration of his state includes such freedom or servitude. ${ }^{65}$

As has been shown, both Wojtyla ${ }^{66}$ and St. Thomas agree that selfdetermination is implied in the intentionality of the act of the will. The Angelic Doctor explains that intention primarily belongs to the will as it tends to an end though means, all in one movement. ${ }^{67}$ Wojtyla, however, adds a further consideration - that introspection would expose that there are certain authentic intentional acts that are not necessarily founded on the dynamic act of the will. Based on the previous contentions of Wojtyla, this would mean that these intentional acts would fall under what is "happening" to man. In other words, these intentional acts belong only to the dynamism of the will insofar as they are supported by self-determination. ${ }^{68}$ In Thomistic terms, this would mean that now freedom becomes a constraint by which intentional

root of the efficacy of the person allows us to reach an even more fundamental understanding of man as the dynamic subject." See Wojtyla, The Acting Person, 100.

${ }^{65}$ St. Thomas associates these concepts in this way: "But that alone seemingly pertains to a man's state, which regards an obligation binding his person, in so far, to wit, as a man is his own master or subject to another, not indeed from any slight or unstable cause, but from one that is firmly established; and this is something pertaining to the nature of freedom or servitude. Therefore state properly regards freedom or servitude whether in spiritual or in civil matters." See ST IIaIIae. 183. 1c.

${ }^{66}$ The interplay between willing, intentionality, and self-determination is explained by our beloved pope in this way: "The objectification that is essential for self-determination takes place together with the intentionality of the particular acts of the will. When I will anything, then I am also determined by myself. Though the ego is not an intentional object of willing its objective being is contained in the nature of acts of willing." See Wojtyla, The Acting Person, 109.

${ }^{67}$ The Angelic Doctor cites an example: "For when I say: 'I wish to take medicine for the sake of health,' I signify no more than one movement of my will. And this is because the end is the reason for willing the means. Now the object, and that by reason of which it is an object, come under the same act; thus it is the same act of sight that perceives color and light, as stated above (Question 8, Article 3, ad 2). And the same applies to the intellect; for if it considers principle and conclusion absolutely, it considers each by a distinct act; but when it assents to the conclusion on account of the principles, there is but one act of the intellect." See ST IaIIae. 12. 4c.

${ }^{68}$ It may be possible to have intentional acts without self-determination, and as such, these are not included in the dynamism of the will. Our beloved pope argues: "Volition as an intentional act is embedded in the dynamism of the will only to the extent self-determination is contained in it. Introspection informs us of the various types of volition that arise in man's interior life and are authentic intentional acts but which are not embedded in the proper dynamism of the will." See Wojtyla, The Acting Person, 110. 


\section{PHILOSOPHICAL ENHANCEMENTS}

acts would fall under the affirmation of "I will" in that person. It is from this latter that Wojtyla would find transcendence.

The internal harmony and cohesion of the person in action, according to Wojtyla, is best expressed by the fulfillment that follows this phenomenon, especially noting that it emanates directly from self-determination.69 Traditionally, self-fulfillment is associated with the notion of the "perfect life" initially by Aristotle and subsequently adopted by the scholastic philosophers. ${ }^{70}$ St. Thomas, who is primarily a Catholic and secondarily a philosopher, considered the perfect life as the kind which was led principally by Christ, ${ }^{71}$ providing testimony to truth, ${ }^{72}$ and consisted of the perfect operation of the totality of man's powers emanating from the beatitude given by God based on merit. ${ }^{73}$ Here we see that the Thomistic process, being teleological, would proceed from the external effects of these good acts - not in the consequentialist sense but on how these reflexively perfect the person - to what ultimately would end up in self-fulfillment. Wojtyla focuses on how action, through efficacy and self-determination, can set the modality of morality in the interplay between inward-ness and outward-ness and

${ }^{69}$ While in Scholastic circles, it is taught that fulfillment is the result of the possession of the object of the faculty, our beloved pope adds that, efficient-wise, it is also caused by the existential and essential coherence of the person: "If so, then undoubtedly the existential and essential cohesion of the person and the action is best and most adequately expressed by the fulfillment resulting from performance of an action." Ibid., 149.

${ }^{70}$ In contemporary times, however, the notion of the perfect life would be difficult to achieve without conforming to the needs of the body. Michael Novak, commenting on Pope John Paul II's encyclical Centesimus Annus, avers: "Pope John Paul II sees that modern conditions are unlike those of the past, even the recent past... However, one important point remains to be made. To establish the moral, philosophical, and religious case for wealth creation is one thing; to find the practical institutions that reach all of the destitute, poor, and vulnerable on this planet and include them in the creative economy is yet another." See Michael Novak, "The Creative Person," in Journal of Business Ethics, 12:12 (1993), 978.

${ }^{71}$ Part of this perfect life, for St. Thomas, is living a life that can be emulated: "Christ wished to make His Godhead known through His human nature. And therefore, since it is proper to man to do so, He associated with men, at the same time manifesting His Godhead to all, by preaching and working miracles, and by leading among men a blameless and righteous life." See ST IIIa. 40. ad 1.

72 In considering on whether Christ should have lived a solitary life, the Angelic Doctor answered in the negative: "I answer that, Christ's manner of life had to be in keeping with the end of His Incarnation, by reason of which He came into the world. Now He came into the world, first, that He might publish the truth. Thus He says Himself (Jn. 18:37): 'For this was I born, and for this came I into the world, that I should give testimony to the truth.' Hence it was fitting not that He should hide Himself by leading a solitary life, but that He should appear openly and preach in public. Hence it was fitting not that He should hide Himself by leading a solitary life, but that He should appear openly and preach in public." See ST IIIa. 40. 2c.

73 The Angelic Doctor explains: "Man's essential reward, which is his beatitude, consists in the perfect union of the soul with God, inasmuch as it enjoys God perfectly as seen and loved perfectly." See ST Suppl. IIIae. 96. 1c.

(c) 2021 Robert A. Montaña

https://www.kritike.org/journal/issue 28/montana june2021.pdf

ISSN 1908-7330

(cc) BY-NC-ND 
between transitiveness and intransitiveness. ${ }^{74}$ Thus, while the relationship between morality and willful intent is most certainly clear for the Angelic Doctor, the emphasis on the person whose morality is the fruit of these relations is a contribution by Wojtyla.

The notion of the acting person goes beyond the mere traditional consideration of man as a psycho-physical unity. While Wojtyla affirms this, his concept of integration pierces towards deeper realities; ${ }^{75}$ and disregarding such may lead to a breakdown of self-possession and self-determination, disintegrating the psychosomatic complexity of the human subject. ${ }^{76}$ With these considerations, Wojtyla proposes the thesis that the unity governing the relation between person and action would have to take precedence over the psychosomatic link in man or, in other words, the transcendent ego should determine a person's subjective ego, not the other way around. ${ }^{77}$ The different manifestations of the ego are a contemporary taxonomy; hence, it would be difficult to contextualize this in traditional terms. We could, however, find a parallel analysis of St. Thomas as regards this dynamic unity when he dealt with the idea of God's predestination of man. Answering the question as to whether predestination is found in the predestined - which in this case is the human person - the Angelic Doctor answered in the negative, arguing that such is found in God who sets man towards eternal life. He, however, clarified that the execution of such an ordering is passive for the predestined, yet active in God. ${ }^{78}$ Here, it is implied that, in the teachings of the Angelic

\footnotetext{
${ }^{74}$ Wojtyla, The Acting Person, 150-151.

${ }^{75}$ It is for this reason that Pope John Paul II was able to clearly demarcate self-possession and self-determination in the various levels of reality. As regards the priesthood of women, Scott Appleby describes Wojtyla's response: “John Paul II has not apologized for continuing to exclude women from the priesthood. His views stem from his reading of the New Testament and the apostolic tradition, from which he concludes that Jesus chose not to include his female disciples among the inner core of apostles. The pope claims that this functional inequality does not undermine the personal equality of men and women, and that dignity of women is not violated by their exclusion from the ordained priesthood." See Scott Appleby, "Pope John Paul II," in Foreign Policy, 119 (2000), 22.

${ }^{76}$ Our beloved pope clarifies that "because of self-determination, an action reaches and penetrates into the subject, into the ego, which is its primary and principal object. Parallel with this there comes the transitiveness and intransitiveness of the human action." See Wojtyla, The Acting Person, 192-193.

77 Our beloved pope associates this relation as an offshoot of man's composite nature: "The subordination of the subjective ego to the transcendent ego - that is to say, the synthesis of efficacy and subjectiveness - in itself implies the complexity as well as the unity of man as a psycho-physical entity." Ibid., 196.

78 This Scholastic truism is compared by the Angelic Doctor with how human government is managed: "But the execution of providence which is called government, is in a passive way in the thing governed, and in an active way in the governor. Whence it is clear that predestination is a kind of type of the ordering of some persons towards eternal salvation, existing in the divine mind. The execution, however, of this order is in a passive way in the predestined, but actively in God." See ST Ia. 23. 2c.
} 


\section{PHILOSOPHICAL ENHANCEMENTS}

Doctor, there is a transcendent order that determines the subjective ordering of man to himself, guiding him towards his perfect life. The additional consideration of the transcendent ego further expands the Thomistic considerations by exposing its congruence with contemporary psychology.

And finally, with man acting together with others, Wojtyla introduces a novel relation which he termed as "intersubjectivity by participation."79 This concept goes far beyond the normal understanding of cooperation inasmuch as he semantically distinguishes it from "acting together with others." Specifically, he explains that the latter is established by the link between action and the value it creates, where the value being personalistic eventually becomes ethical, and thus establishes the participatory characteristic of authentic communal action. ${ }^{80}$ St. Thomas seemed to have achieved the same conclusion, however, by first establishing that charity is the most excellent of all virtues and by equating it with friendship for others, distinguishing the latter from the love of self ${ }^{81}$ which turns this charity into a kind of concupiscence. ${ }^{82}$ Both paths leading to love of neighbor, one having personalistic action as its starting point and the other one with charity as foundation, establishes a complementary link. This is another clear contribution by Wojtyla.

${ }^{79}$ Edward Collins Vacek expounds on this concept: "For Wojtyla, participation means persons acting jointly for a common good, while at the same time fulfilling themselves as unique persons. These persons are not diminished for the sake of an external goal. Rather, in mutuality, otherness is preserved and greater personalization is achieved by all participants. Alienation, by contrast, means losing the experience of the other as another 'I." See Edward Collins Vacek, "John Paul II and Cooperation with God," in The Annual of the Society of Christian Ethics, 10 (1990), 82.

${ }^{80}$ Our beloved pope here is referring to personalistic action: "We will then notice that the performance itself of an action by the person is a fundamental value, which we may call the personalistic - personalistic or personal-value of the action. Such a value differs from all moral values, which belong to the nature of the performed action and issue from their reference to a norm." See Wojtyla, The Acting Person, 261-271.

81 Contemporary philosophers have various interpretations of this distinction. Commenting on Karol Wojtyla's philosophy of love, Jaroslaw Merecki asserts: “... we distinguish two kinds of good: a good as appetibile (and this type of good is conceptualized in the Thomistic notion) and a good as affirmabile... These two types of goodness require two different responses from the subject: in the case of the good as appetibile the response is motivated by my own good, whereas in the case of the good as affirmabile the response is motivated by the good of the object of my action. This requires a reformulation of the Thomistic philosophy of the will." See Jaroslaw Merecki, "Some Remarks on the Philosophy of Love in Dietrich Von Hilderbrand and Karol Wojtyla," in Annals of Philosophy, 60:3 (2012), 8.

${ }^{82}$ In other words, for St. Thomas, such love must be integrated with benevolence: "According to the Philosopher (Ethic. viii, 2,3) not every love has the character of friendship, but that love which is together with benevolence, when, to wit, we love someone so as to wish good to him." See ST IIaIIae. 23. 1c.

(c) 2021 Robert A. Montaña

https://www.kritike.org/journal/issue 28/montana june2021.pdf

ISSN 1908-7330

(cc) BY-NC-ND 


\section{Final Reflection}

The analytic understanding of phenomenon has been placed under the scrutiny of reason once again after Karol Wojtyla has fused the traditional and contemporary notions of phenomenon, integrating the notion of transcendence without sacrificing its grounded-ness and relevance today. By bringing attention back into the person as the crux not only of action but also of experience, our beloved pope has trodden the path through which reduction could paradoxically enrich man's wisdom by going beyond the rudimentary knowledge of one's essence, educing instead the dynamic implications of the human act and its relation to the person treated as someone rather than as something.

Since man has been the subject of scientific studies by diverse fields, there had been dangerous tendencies to reduce him to the limitations of the phenomenological method, not necessary the phenomenological understanding of man as personalistic. Even the most sacred of man's inner life-his consciousness-has been subjected to scrutiny leading to interpretations that considers him as a luck branch of evolutionary wonder. Religious and Scholastic notions of man as a transcendent being, or at least one that is capable of transcendence, has been treated as a confection of culture or a satisfaction of an anamorphic need for self-esteem, but in serious academic matters, it has been taught that consciousness is just an effective means of survival of the species, and eventually of the human genome. Yet when problems revolving man's existence and his choices begin to wear down his resolve, these analytic interpretations of man begin to further increase anxiety because he begins to see the meaninglessness of his proximate ends. From this man begins to understand his spirituality both in the ontological sense as emphasized by the Angelic Doctor and in the phenomenological perspective offered by our beloved pope.

The further reduction of choice in the behavioral sciences as a mere directive to what is advantageous to an organism has taken a toll on certain moral values and virtues such as justice and mercy. Yet the interplay between will and reason has long been clarified by the Angelic Doctor, enhanced by our beloved pope by integrating the notion of efficacy whereby the intricate connection between the action and the person is further established. These teachings bring to light the fundamental answer to the root cause of human happiness that has perplexed science since it could not adequately be explained by the simple acquisition of well-being.

Even the contradictions in the adjudication of cases involving human choice where judges sometimes affirm the natural in man or positively reduce law to simply what has been enacted has led the academic legal luminaries to eventually posit not only a moral reading of their constitutions but also agree

(C) 2021 Robert A. Montaña

https://www.kritike.org/journal/issue 28/montana june2021.pdf

ISSN 1908-7330

(cc) BY-NC-ND 


\section{PHILOSOPHICAL ENHANCEMENTS}

that the nature is beyond written agreements, indirectly also affirming the teachings of St. Thomas and Wojtyla that man's self-determination is ultimately related to a proper understanding of a nature that is congruent with eternal law.

The gradual and unfortunate setting aside of Thomism and the antiphonic elevation of positivistic phenomenology has led to the disregard of the personalistic and humanistic perspective. The philosophy of Pope Saint John Paul II has invigorated the interest in the old and tested ways of living the perfect life, breathing a new soul into how such tradition can still be suited to the contemporary and scientific man reflecting upon the true meaning of his inner self.

Department of Philosophy, University of Santo Tomas, Philippines

\section{References}

Aguas, Jove Jim, "The Notions of the Human Person and Human Dignity in Aquinas and Wojtyla," in Kritike: An Online Journal of Philosophy, 3:1 (June 2009), <http://www.kritike.org/journal/issue_5/ aguas_june2009.pdf $>$.

Appleby, Scott, "Pope John Paul II," in Foreign Policy, 119 (2000).

Bagood, Albert, "John Paul II's Discrete Eye for Science," in Angelicum, 82:2 (2005).

Baumann, Klaus, "The Concept of Human Acts Revisited: St. Thomas and the Unconscious in Freedom," in Gregorianum, 80:1 (1999).

Burgos, Juan Manuel, An Introduction to Personalism, (USA: The Catholic University of America Press, 2018).

"The Method of Karol Wojtyla: A Way Between Phenomenology, Personalism and Metaphysics," Phenomenology and Existentialism in the Twentieth Century: Book Two, Fruition: Cross PollinationDissemination, ed. by A-T Tymieniecka (Springer Netherlands, 2009), 107-129.

"Wojtyla's Personalism as Integral Personalism," in Quaestiones Disputatae, 9:2 (Spring 2019), 91-111.

Coughlin, John, "Canon Law and the Human Person," Journal of Law and Religion, 19:1 (Cambridge: Cambridge University Press, 2003-2004).

Dougherty, Jude, "Phenomenology as 'Ancilla Theologiae," in Angelicum, 82:2 (2005).

Dybciak, Krzysztof and Alice-Catherine Carls, "The Poetic Phenomenology of a Religious Man: About the Literary Creativity of Karol Wojtyla," in World Literature Today, 54:2 (1980).

(c) 2021 Robert A. Montaña

https://www.kritike.org/journal/issue 28/montana june2021.pdf

ISSN 1908-7330

(c) $)$ BY-NC-ND 
Galkowski, Jerzy, "The Place of Thomism in the Anthropology of K. Wojtyla," in Angelicum, 65:2 (1988).

Gilson, Etienne. The Christian Philosophy of St. Thomas Aquinas, (USA: Notre Dame Press, 1956).

Gendreau, Bernard "The Role of Jacques Maritain and Emmanuel Mounier in the Creation of French Personalism," in The Personalist Forum, 8:1 (1992).

Grondelski, John, "Nature and Natural Law in the Pre-Pontifical Thought of John Paul II," in Angelicum, 72:4 (1995). "Prepapal Influences on John Paul II's Thought," in New Blackfriars, 78:911 (1997).

Hellman, John, "John Paul II and the Personalist Movement," in CrossCurrents, 30:4 (1980-1981).

Jiang, Lu, "Person and freedom in Thomas Aquinas' philosophy," in Divus Thomas, 121:3 (2018).

Kochler, Hans, "The Phenomenology of Karol Wojtyla: On the Problem of the Phenomenological Foundation of Anthropology," in Philosophy and Phenomenological Research, 42:3 (1982).

Kraszewski, Gracjan, “Catalyst for Revolution: Pope John Paul II's 1979 Pilgrimage to Poland and Its Effects on Solidarity and the Fall of Communism," in The Polish Review, 57:4 (2012).

Lichten, Joseph, "A Pope of Great Hopes," in The Polish Review, 24:2, Gaude Mater Polonia: Special Issue Dedicated to Karol Cardinal Wojtyla, John Paul II Pontifex Maximus (1979).

Liszka, James, "The Philosophical Thought of Cardinal Karol Wojtyla," in The Polish Review, 24:2 (1979).

Merecki, Jaroslaw, "Some Remarks on the Philosophy of Love in Dietrich Von Hilderbrand and Karol Wojtyla," in Annals of Philosophy, 60:3 (2012).

Montaña, Robert, Thomistic Ethics: A Beacon in the Contemporary Moral Landscape, (Manila: University of Santo Tomas Publishing House, 2015).

Muscari, Paul, "On Human Nature: A Look at the Subject from Karol Wojtyla's Work 'The Acting Person," in The Journal of Mind and Behavior, 9:1 (1988).

Novak, Michael, "The Creative Person," in Journal of Business Ethics, 12:12 (1993).

Salas, Victor, "The Analogical Structure of Self-Giving and Receiving according to John Paul II," in Gregorianum, 90:3 (2009).

"Thomas Aquinas's Metaphysics of the Person and Phenomenological Personalism: The Case of Incommunicability," in Gregorianum, 94:3 (2013).

(C) 2021 Robert A. Montaña

https://www.kritike.org/journal/issue 28/montana june2021.pdf

ISSN 1908-7330 


\section{PHILOSOPHICAL ENHANCEMENTS}

Taylor, Jameson, "Karol Wojtyla's Development of the Traditional Definition of Personhood," in The Review of Metaphysics 63:2 (2009).

Thomas of Aquinas, The Summa Theologica, trans. the Fathers of the English Dominican Province (New York: Benziger Bros Edition, 1947).

Vacek, Edward Collins, "John Paul II and Cooperation with God," in The Annual of the Society of Christian Ethics, 10 (1990).

Williams, Huntston, "John Paul II's Concepts of Church, State, and Society," in Journal of Church and State, 24:3 (1982).

Wojtyla, Karol, The Acting Person (Dordrecht, Holland: D. Reidel Publishing Company, 1979).

"The Person: Subject and Community," in The Review of Metaphysics, 33:2 (1979). 